\title{
Weight Analysis of the Factors Affecting eWOM Providing Behavior
}

\author{
Elvira Ismagilova ${ }^{1(\bowtie)}$, Yogesh K. Dwivedi ${ }^{2}$, Nripendra P. Rana ${ }^{1}$, \\ Uthayasankar Sivarajah $^{1}$, and Vishanth Weerakkody ${ }^{1}$ \\ ${ }^{1}$ Faculty of Management, Law and Social Sciences, \\ University of Bradford, Bradford, UK \\ \{e. ismagilova, n. p. rana, u. sivarajah, \\ v.weerakkody\}@bradford.ac.uk \\ ${ }^{2}$ Emerging Markets Research Centre, School of Management, \\ Swansea University, Swansea, UK \\ y.k.dwivedi@swansea.ac.uk
}

\begin{abstract}
Electronic word of mouth (eWOM) significantly affects the consumer decision-making process. A number of studies investigated why consumers provide eWOM communications. Existing literature has contradicting factors regarding factors affect eWOM providing behaviour. This study aims to evaluate factors affecting eWOM providing behaviour by performing a systematic review and weight analysis of existing research outputs. Based on the result of weight analysis it was found that the best predictors of eWOM providing behaviour are involvement, self-enhancement, and trust in web eWOM services. Scholars can use the results of this study when making decisions regarding the inclusion of factors in their research. Practitioners can pay more attention to the best predictors.
\end{abstract}

Keywords: eWOM, weight analysis $\cdot$ Literature review $\cdot$ eWOM providing behaviour

\section{Introduction}

Electronic word of mouth (eWOM) significantly affects the consumer decision-making process $[1,2]$. eWOM is defined as "the dynamic and on-going information exchange process between potential, actual, or former consumers regarding a product, service, brand, or company, which is available to a multitude of people and institutions via the Internet" [3].

An increasing number of researchers and practitioners have started paying attention to eWOM communications [4-6]. A number of studies investigated factors affecting eWOM providing behaviour [7-10]. Existing studies in this area have reported conflicting results on the effect of factors affecting eWOM providing behaviour. For instance, Luarn et al. [11] found that altruism does not affect eWOM providing behaviour, while Cui et al. [12] found that altruism has a significant positive effect on eWOM providing behaviour. Another study by Shen et al. [13] by using surveys found that economic incentives do not have any significant impact on eWOM providing 
behaviour, while Son et al. [14] found the opposite results-economic incentives positively affect individual's behaviour to provide eWOM. The mixed findings on the factors affecting eWOM providing behaviour can lead to confusion for scholars and practitioners.

Thus, it is crucial to conduct a review of existing studies on eWOM providing behaviour and perform weight analysis. Thus, the aim of this research is to examine factors affecting eWOM providing behaviour by performing a systematic review and weight analysis of existing research findings. Conducting weight analysis will help to investigate the predictive power of the independent variables on the dependent variables, by taking into account the number of times a relationship has been previously studied. The model developed through the weight analysis will help eWOM practitioners and scholars to focus on more influential factors of eWOM providing behaviour.

The remaining part of the paper is organised in the following way. Section 2 focuses on the method which was used for this study. Section 3 will present the literature review. After, the findings from weight analysis are presented and discussed in Sect. 4. Section 5 presents a conclusion followed by the limitations of this study and directions for future research.

\section{Literature Search Method}

To perform weight analysis peer-reviewed journal articles on eWOM communications were collected from bibliographic database Scopus, which is one of the world's largest abstract and citation databases of peer-reviewed literature. The searched keywords were selected after consulting the experts and included "Online review", "Online reviews", "Electronic word-of-mouth", "Electronic word of mouth", "eWOM", "Internet wordof-mouth", "Internet word of mouth", “iWOM", "Online word-of-mouth", “Online word of mouth", "Virtual word-of-mouth". As a result, more than 500 articles were identified published from 2000 untill 2018. Articles that did not focus on eWOM providing behaviour and did not have empirical findings were excluded, leaving 54 research papers relevant for this research.

\section{Literature Synthesis}

An extensive number of studies investigated factors affecting eWOM providing behaviour. The studies were conducted in different contexts (e.g. SNS, opinion platforms, online review websites), countries (e.g. USA, China, Spain), using different products and services as examples (e.g. laptop, restaurants, hotels) [9, 15-18]. Additionally, studies used various methods for data collection such as surveys or data mining $[19,20]$. Studies applied a number of theories to study factors affecting eWOM providing behaviour such as social exchange theory, motivational theory and Uses and Gratification theory to name a few [17]. Based on the literature review 21 factors which affect eWOM providing behaviour were identified (see Table 1). 
Table 1. Factors affecting eWOM providing behaviour

\begin{tabular}{|c|c|c|c|}
\hline Construct & Definition & $\begin{array}{l}\text { Number } \\
\text { of } \\
\text { studies }\end{array}$ & $\begin{array}{l}\text { Representative } \\
\text { studies }\end{array}$ \\
\hline $\begin{array}{l}\text { Influence of } \\
\text { others }\end{array}$ & $\begin{array}{l}\text { Influence by the behaviours and practices } \\
\text { of other users }\end{array}$ & 6 & {$[7,8]$} \\
\hline $\begin{array}{l}\text { Information } \\
\text { influence }\end{array}$ & $\begin{array}{l}\text { Capacity to accept information from } \\
\text { another knowledgeable person to select a } \\
\text { product or brand }\end{array}$ & 4 & {$[9,10]$} \\
\hline Tie strength & $\begin{array}{l}\text { The depth of a relationship between } \\
\text { source and information seeker. Variables } \\
\text { included: tie strength, social interaction } \\
\text { tie, perceived social relationships }\end{array}$ & 7 & {$[21,22]$} \\
\hline Homophily & $\begin{array}{l}\text { The degree to which two or more } \\
\text { individuals who interact are similar in } \\
\text { certain attributes (e.g. beliefs, education, } \\
\text { social status) }\end{array}$ & 3 & {$[9,15]$} \\
\hline $\begin{array}{l}\text { Economic } \\
\text { incentive }\end{array}$ & $\begin{array}{l}\text { Getting economic benefits (e.g. money, } \\
\text { web coupons, free delivery). Variables } \\
\text { included: economic incentive, } \\
\text { remuneration, extrinsic reward, open } \\
\text { market reward }\end{array}$ & 12 & {$[13,14]$} \\
\hline Altruism & $\begin{array}{l}\text { The aim of increasing welfare of one or } \\
\text { more person(s) other than oneself }\end{array}$ & 8 & {$[11,12]$} \\
\hline $\begin{array}{l}\text { Self- } \\
\text { enhancement }\end{array}$ & $\begin{array}{l}\text { Presenting themselves positively, sharing } \\
\text { information to look good }\end{array}$ & 12 & {$[12,23]$} \\
\hline $\begin{array}{l}\text { Satisfaction in } \\
\text { helping other } \\
\text { customers }\end{array}$ & $\begin{array}{l}\text { Pleasant consumption fulfilment which } \\
\text { happens as a result of helping other } \\
\text { customers }\end{array}$ & 4 & {$[17,18]$} \\
\hline Opinion seeking & $\begin{array}{l}\text { Behaviour focused on looking for } \\
\text { eWOM communications }\end{array}$ & 3 & {$[24,25]$} \\
\hline $\begin{array}{l}\text { Opinion } \\
\text { leadership }\end{array}$ & $\begin{array}{l}\text { A domain-independent, trait-like set of } \\
\text { personality characteristics that are stable } \\
\text { over time and across respondent groups. } \\
\text { Opinion leaders shape public opinion by } \\
\text { selectively conveying mass media } \\
\text { messages to their social networks }\end{array}$ & 3 & {$[25,26]$} \\
\hline $\begin{array}{l}\text { Community } \\
\text { identity }\end{array}$ & $\begin{array}{l}\text { Sense of belonging to the virtual (online) } \\
\text { community. Variables included: } \\
\text { community identification, social } \\
\text { identification }\end{array}$ & 3 & {$[20,27]$} \\
\hline Reciprocity & $\begin{array}{l}\text { Benefit for individuals to engage in } \\
\text { social exchange; a person who offers } \\
\text { help to others is expecting returns in the } \\
\text { future }\end{array}$ & 2 & {$[19,20]$} \\
\hline
\end{tabular}


Table 1. (continued)

\begin{tabular}{|c|c|c|c|}
\hline Construct & Definition & $\begin{array}{l}\text { Number } \\
\text { of } \\
\text { studies }\end{array}$ & $\begin{array}{l}\text { Representative } \\
\text { studies }\end{array}$ \\
\hline $\begin{array}{l}\text { Information } \\
\text { usefulness }\end{array}$ & $\begin{array}{l}\text { The degree to which the information } \\
\text { assists consumers in making their } \\
\text { purchase decisions }\end{array}$ & 3 & {$[28,29]$} \\
\hline $\begin{array}{l}\text { Affective } \\
\text { commitment }\end{array}$ & $\begin{array}{l}\text { Affective (emotional) commitment } \\
\text { derived from emotional attachment to, } \\
\text { identification with, and involvement in } \\
\text { an entity }\end{array}$ & 2 & {$[30,31]$} \\
\hline $\begin{array}{l}\text { Normative } \\
\text { commitment }\end{array}$ & $\begin{array}{l}\text { Motivated by the actor's moral } \\
\text { obligation that } \mathrm{s} / \text { he must fulfil }\end{array}$ & 2 & {$[30,31]$} \\
\hline Involvement & $\begin{array}{l}\text { The degree of psychological } \\
\text { identification and emotional ties the } \\
\text { receiver has with the product/service }\end{array}$ & 8 & {$[12,32]$} \\
\hline $\begin{array}{l}\text { Customer } \\
\text { satisfaction }\end{array}$ & $\begin{array}{l}\text { A condition that happens as a result of a } \\
\text { pleasant consumption fulfilment }\end{array}$ & 8 & {$[16,33]$} \\
\hline Loyalty & $\begin{array}{l}\text { Overall attachment with a favourable } \\
\text { attitude manifested by repeated } \\
\text { purchasing }\end{array}$ & 3 & {$[14,16]$} \\
\hline Perceived risk & $\begin{array}{l}\text { The uncertainty a consumer has in } \\
\text { making a purchase decision }\end{array}$ & 3 & {$[18,34]$} \\
\hline Brand loyalty & Favourable attitude toward the brand & 2 & {$[35,36]$} \\
\hline $\begin{array}{l}\text { Trust in web } \\
\text { eWOM services }\end{array}$ & $\begin{array}{l}\text { The subjective belief that a party will } \\
\text { fulfil their obligations }\end{array}$ & 4 & {$[20,37]$} \\
\hline
\end{tabular}

To determine the strength of the relationships between constructs, weight analysis was conducted by dividing the number of significant relationships by the total number of analysed relationships between studied independent and dependent variables. For example, the relationship between economic incentive and engaging in eWOM communications was examined 13 times and was significant eight times. As a result, the weight significance of a relationship between these two constructs is calculated by dividing 8 by 13 , which gives 0.615 . If weight is equal to 1 it indicates that the relationship between two constructs is significant across all studies, while a weight equal to 0 shows this relationship is non-significant throughout all examined studies (Jeyaraj et al. [39]; Rana et al. [40]). Table 2 presents the weight analysis of all 21 relationships included in this study.

Researchers [38-40] classify predictors as follows: a predictor is 'well-utilised' if examined five or more times, otherwise it is considered as 'experimental'; a predictor is a 'best predictor' if its weight is greater or equal to 0.8 and it has been examined more than five times but is a 'promising predictor' if it has been examined less than 5 times and has a weight of 1 . 
Table 2. Results of weight analysis

\begin{tabular}{|c|c|c|c|c|}
\hline $\begin{array}{l}\text { Independent } \\
\text { variable }\end{array}$ & $\begin{array}{l}\text { Number of } \\
\text { significant } \\
\text { relationships }\end{array}$ & $\begin{array}{l}\text { Number of non- } \\
\text { significant } \\
\text { relationships }\end{array}$ & $\begin{array}{l}\text { Total number } \\
\text { of } \\
\text { relationships }\end{array}$ & Weight \\
\hline $\begin{array}{l}\text { Satisfaction in } \\
\text { helping other } \\
\text { customers }\end{array}$ & 4 & 0 & 4 & 1.000 \\
\hline Opinion seeking & 3 & 0 & 3 & 1.000 \\
\hline Opinion leadership & 4 & 0 & 4 & 1.000 \\
\hline $\begin{array}{l}\text { Information } \\
\text { usefulness }\end{array}$ & 4 & 0 & 4 & 1.000 \\
\hline $\begin{array}{l}\text { Affective } \\
\text { commitment }\end{array}$ & 3 & 0 & 3 & 1.000 \\
\hline $\begin{array}{l}\text { Normative } \\
\text { commitment }\end{array}$ & 3 & 0 & 3 & 1.000 \\
\hline Loyalty & 3 & 0 & 3 & 1.000 \\
\hline Perceived risk & 3 & 0 & 3 & 1.000 \\
\hline $\begin{array}{l}\text { Trust in web } \\
\text { eWOM services }\end{array}$ & 5 & 0 & 5 & 1.000 \\
\hline Self-enhancement & 12 & 1 & 13 & 0.923 \\
\hline Involvement & 7 & 1 & 8 & 0.875 \\
\hline Brand loyalty & 2 & 1 & 3 & 0.667 \\
\hline $\begin{array}{l}\text { Economic } \\
\text { incentive }\end{array}$ & 8 & 5 & 13 & 0.615 \\
\hline Altruism & 5 & 4 & 9 & 0.556 \\
\hline $\begin{array}{l}\text { Customer } \\
\text { satisfaction }\end{array}$ & 5 & 4 & 9 & 0.556 \\
\hline Influence of others & 3 & 3 & 6 & 0.500 \\
\hline Tie strength & 4 & 4 & 8 & 0.500 \\
\hline $\begin{array}{l}\text { Community } \\
\text { identity }\end{array}$ & 2 & 2 & 4 & 0.500 \\
\hline Homophily & 1 & 2 & 3 & 0.333 \\
\hline Reciprocity & 1 & 2 & 3 & 0.333 \\
\hline $\begin{array}{l}\text { Information } \\
\text { influence }\end{array}$ & 1 & 4 & 5 & 0.200 \\
\hline
\end{tabular}

Note: Dependent variable is eWOM providing behavior

The following predictors of intention to provide eWOM communications fall within the category of best predictor: involvement (examined 8 times, significant 7 times), self-enhancement (examined 13 times, significant 12 times), and trust in web eWOM services (examined 5 times, significant 5 times). All of these predictors were explored five or more times and have a weight equal to or greater than 0.80 .

Predictors such as information usefulness (examined 4 times, significant 4 times), affective commitment (examined 3 times, significant 3 times), normative commitment (examined 3 times, significant 3 times), loyalty (examined 3 times, significant 3 times), 
perceived risk (examined 3 times, significant 3 times), opinion seeking (examined 3 times, significant 3 times), and opinion leadership (examined 4 times, significant 4 times) are considered as promising predictors of intention to engage in eWOM communications. Although these relationships were found to be significant across all examined studies, Jeyaraj et al. [39] suggest that these types of experimental variables need more testing to be categorised as best predictors.

Even though none of the studied relationships between predictors and intention to engage in eWOM was found to have a weight of ' 0 ', some of the well-utilised independent constructs are considered to be least effective predictors, such as influence of others (examined 6 times, significant 3 times), tie strength (examined 8 times, significant 4 times), information influence (examined 5 times, significant once), economic incentive (examined 13 times, significant 8 times), altruism (examined 9 times, significant 5 times), and customer satisfaction (examined 9 times, significant 5 times). It is proposed by Jeyaraj et al. [39] that justification for continuing to examine such predictors should be convincing. Nevertheless, it may be premature to exclude such predictors given that eWOM providing behaviour research is still emerging as far as the empirical aspects and solid theoretical foundations of this research are concerned. Out of the total 21 examined relationships only nine were found to be studied five or more times (influence of others, tie strength, information influence, economic incentive, altruism, involvement, self-enhancement, customer satisfaction, and trust in web eWOM services), which proposes that eWOM research is still not that well developed. Moreover, some researchers propose that weight analysis may not be a sufficient reason to exclude any variables from further analysis (Rana et al. [40]). None of the predictors was found to be the worst predictors of intention to engage in eWOM communications.

\section{Discussion}

Taking into account the increasing number of studies on eWOM providing behaviour, it is important to discuss and analyse their collective findings. Figure 1 presents the diagrammatic representation of the factors affecting eWOM providing behaviour with their corresponding weight based on the results of weight analysis. The findings suggest the best predictors such as involvement, self-enhancement, and trust in web eWOM services should be included in eWOM research. Promising predictors such as should be included in future empirical research to evaluate their overall performance. 


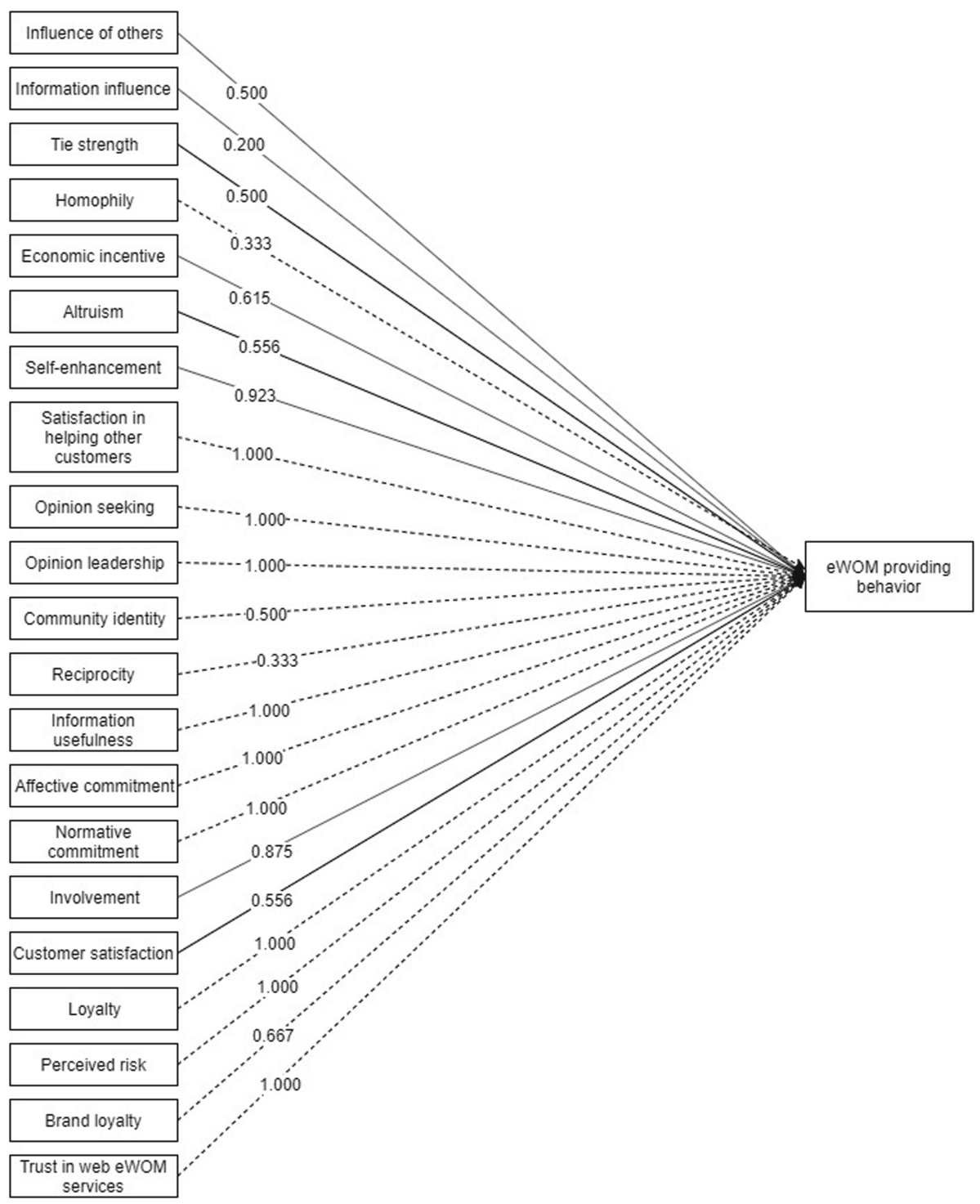

Fig. 1. Factors affective eWOM providing behaviour Note: - - > experimental predictors; $\rightarrow$ well-utilised predictors.

\section{Conclusion and Limitations}

The aim of this research was to examine factors affecting eWOM providing behaviour by conducting weight analysis of existing research findings. The weight analysis was performed by identifying a number of significant and non-significant relationships between studied variables. 
The current study provides some implications for researchers and practitioners. This research provided a framework for future research identifying factors affecting eWOM providing behaviour. Scholars can use the results of this study when making decisions regarding the inclusion of factors in their research. Practitioners can pay more attention to the best predictors- involvement, self-enhancement, and trust in web eWOM services.

The current research has a number of limitations. First, this study only conducted weight analysis without performing meta-analysis which could strengthen those findings of weight analysis and evaluate the significance of the studies relationships [41]. It is advised that future research performs meta-analysis on factors affecting eWOM providing behaviour. Second, this study only used the Scopus database for the collection of study. This can affect the number of research outputs available for weight analysis, the coverage and representativity of the sample considered in the analysis. Thus, future research should employ other available datasets (e.g. web of science, Google Scholar, EBSCO).

\section{References}

1. Dwivedi, Y.K., Kapoor, K.K., Chen, H.: Social media marketing and advertising. Market. Rev. 15, 289-309 (2015)

2. Alalwan, A.A., Rana, N.P., Dwivedi, Y.K., Algharabat, R.: Social media in marketing: a review and analysis of the existing literature. Telematics Inform. 34, 1177-1190 (2017)

3. Ismagilova, E., Dwivedi, Y.K., Slade, E., Williams, M.D.: Electronic Word of Mouth (eWOM) in the Marketing Context: A State of the Art Analysis and Future Directions. Springer, Heidelberg (2017). https://doi.org/10.1007/978-3-319-52459-7

4. Rathore, A.K., Ilavarasan, P.V., Dwivedi, Y.K.: Social media content and product cocreation: an emerging paradigm. J. Enterprise Inf. Manag. 29, 7-18 (2016)

5. Shareef, M.A., Mukerji, B., Dwivedi, Y.K., Rana, N.P., Islam, R.: Social media marketing: comparative effect of advertisement sources. J. Retailing Consumer Serv. 46, 58-69 (2019)

6. Shiau, W.-L., Dwivedi, Y.K., Yang, H.S.: Co-citation and cluster analyses of extant literature on social networks. Int. J. Inf. Manag. 37, 390-399 (2017)

7. Choi, J.H., Scott, J.E.: Electronic word of mouth and knowledge sharing on social network sites: a social capital perspective. J. Theoret. Appl. Electron. Commer. Res. 8, 69-82 (2013)

8. Christodoulides, G., Michaelidou, N., Argyriou, E.: Cross-national differences in e-WOM influence. Eur. J. Market. 46, 1689-1707 (2012)

9. Saleem, A., Ellahi, A.: Influence of electronic word of mouth on purchase intention of fashion products in social networking websites. Pak. J. Commer. Soc. Sci. (PJCSS) 11, 597622 (2017)

10. Wu, L., Mattila, A.S., Wang, C.-Y., Hanks, L.: The impact of power on service customers' willingness to post online reviews. J. Serv. Res. 19, 224-238 (2016)

11. Luarn, P., Chiu, Y.-P., Yang, J.-C.: An exploratory study of the motives engaged in the dissemination of social word-of-mouth via mobile device. In: 2014 47th Hawaii International Conference on System Sciences, pp. 1033-1042. IEEE (2014)

12. Cui, J., Wang, L., Feng, H., Teng, Y.: Empirical study of the motivations of E-WOM spreading on online feedback system in China. In: PACIS, p. 251 (2014) 
13. Shen, W., Cai, J., Li, L.: Electronic word-of-mouth in China: a motivational analysis. In: 2011 International Conference on E-Business and E-Government (ICEE), pp. 1-6. IEEE (2011)

14. Son, J.-E., Kim, H.-W., Jang, Y.-J.: Investigating factors affecting electronic word-of-mouth in the open market context: a mixed methods approach. In: PACIS, p. 167 (2012)

15. Hansen, S.S., Lee, J.K.: What drives consumers to pass along marketer-generated eWOM in social network games? Social and game factors in play. J. Theoret. Appl. Electron. Commer. Res. 8, 53-68 (2013)

16. Lee, J., Lee, J.-N., Tan, B.C.: The contrasting attitudes of reviewer and seller in electronic word-of-mouth: a communicative action theory perspective. Asia Pac. J. Inf. Syst. 23, 105129 (2013)

17. Tong, Y., Wang, X., Tan, C.-H., Teo, H.-H.: An empirical study of information contribution to online feedback systems: a motivation perspective. Inf. Manag. 50, 562-570 (2013)

18. Zhang, Y., Lv, T.: Analysis of the relationship between involvement and the internet wordof-mouth. In: 2010 2nd IEEE International Conference on Network Infrastructure and Digital Content, pp. 1018-1024. IEEE (2010)

19. Cheung, C.M., Lee, M.K.: What drives consumers to spread electronic word of mouth in online consumer-opinion platforms. Decis. Support Syst. 53, 218-225 (2012)

20. Horng, S.-M.: A study of active and passive user participation in virtual communities. J. Electron. Commer. Res. 17, 289-311 (2016)

21. Niu, H., Wang, X., Sun, N.: Influences of external incentives on consumers' positive electronic word-of-mouth intention. Mark. Sci. Innov. Econ. Dev. 236-244 (2010)

22. Wolny, J., Mueller, C.: Analysis of fashion consumers' motives to engage in electronic word-of-mouth communication through social media platforms. J. Market. Manag. 29, 562583 (2013)

23. Hennig-Thurau, T., Gwinner, K.P., Walsh, G., Gremler, D.D.: Electronic word-of-mouth via consumer-opinion platforms: what motivates consumers to articulate themselves on the internet? J. Interact. Market. 18, 38-52 (2004)

24. Nagy, A., Kemény, I., Szűcs, K., Simon, J., Kiss, V.: Are opinion leaders more satisfied? Results of a SEM model about the relationship between opinion leadership and online customer satisfaction. Soc. Econ. 39, 141-160 (2017)

25. Sun, T., Youn, S., Wu, G., Kuntaraporn, M.: Online word-of-mouth (or mouse): an exploration of its antecedents and consequences. J. Comput.-Mediated Commun. 11, 1104 1127 (2006)

26. Kucukemiroglu, S., Kara, A.: Online word-of-mouth communication on social networking sites: an empirical study of Facebook users. Int. J. Commer. Manag. 25, 2-20 (2015)

27. Yoo, C.W., Sanders, G.L., Moon, J.: Exploring the effect of e-WOM participation on eLoyalty in e-commerce. Decis. Support Syst. 55, 669-678 (2013)

28. Frasquet, M., Ruiz-Molina, M.-E., Molla-Descals, A.: The role of the brand in driving online loyalty for multichannel retailers. Int. Rev. Retail Distrib. Consum. Res. 25, 490-502 (2015)

29. Huang, L., Shao, J., Wang, W.: Research on the relationships between hotel internet wordof-mouth and customers' behavior intention based on trust. In: 2013 6th International Conference on Information Management, Innovation Management and Industrial Engineering, pp. 250-254. IEEE (2013)

30. Jin, X., Xiang, L., Lee, M.K., Cheung, C.M., Zhou, Z., Zhao, D.-T.: Electronic word-ofmouth contribution continuance in online opinion platforms: the role of multiple commitments. In: PACIS, p. 149 (2010)

31. Li, C.-H., Chang, C.-M.: The influence of trust and perceived playfulness on the relationship commitment of hospitality online social network-moderating effects of gender. Int. J. Contemp. Hospitality Manag. 28, 924-944 (2016) 
32. De Meyer, C., Petzer, D.: Product involvement and online word-of-mouth in the South African fast food industry. READINGS BOOK 205 (2013)

33. Lii, Y.-S., Lee, M.: The joint effects of compensation frames and price levels on service recovery of online pricing error. Manag. Serv. Qual.: Int. J. 22, 4-20 (2012)

34. Tirunillai, S., Tellis, G.J.: Does chatter really matter? Dynamics of user-generated content and stock performance. Market. Sci. 31, 198-215 (2012)

35. Rialti, R., Zollo, L., Pellegrini, M.M., Ciappei, C.: Exploring the antecedents of brand loyalty and electronic word of mouth in social-media-based brand communities: do gender differences matter? J. Glob. Market. 30, 147-160 (2017)

36. Yeh, Y.-H., Choi, S.M.: MINI-lovers, maxi-mouths: an investigation of antecedents to eWOM intention among brand community members. J. Market. Commun. 17, 145-162 (2011)

37. Nusair, K., Hua, N., Ozturk, A., Butt, I.: A theoretical framework of electronic word-ofmouth against the backdrop of social networking websites. J. Travel Tourism Market. 34, 653-665 (2017)

38. Ismagilova, E., Slade, E.L., Rana, N.P., Dwivedi, Y.K.: The effect of electronic word of mouth communications on intention to buy: a meta-analysis. Inf. Syst. Front. 1-24 (2019). https://doi.org/10.1007/s10796-019-09924-y

39. Jeyaraj, A., Rottman, J.W., Lacity, M.C.: A review of the predictors, linkages, and biases in IT innovation adoption research. J. Inf. Technol. 21, 1-23 (2006)

40. Rana, N.P., Dwivedi, Y.K., Williams, M.D.: A meta-analysis of existing research on citizen adoption of e-government. Inf. Syst. Front. 17, 547-563 (2015)

41. Dwivedi, Y.K., Rana, N.P., Jeyaraj, A., Clement, M., Williams, M.D.: Re-examining the unified theory of acceptance and use of technology (UTAUT): towards a revised theoretical model. Inf. Syst. Front. 21, 719-734 (2019) 